\title{
Comparative Life Cycle Assessment of Different Vacuum Insulation Panel Core Materials using a Cradle to Gate Approach
}

\author{
Shahaboddin Resalati*1, Tobechi Okoroafor ${ }^{1}$, Paul Henshall ${ }^{1}$, Nuno Simões ${ }^{2,3}$, Márcio \\ Gonçalves ${ }^{2,3}$, Mahmood Alam ${ }^{4}$ \\ ${ }^{1}$ Oxford Brookes University, Headington Campus, Gipsy Lane, OX3 OBP, Oxford, United Kingdom \\ ${ }^{2}$ ADAI, Dept. of Civil Engineering, University of Coimbra, Rua Luís Reis Santos - Pólo II 3030-788 Coimbra, \\ Portugal
}

${ }^{3}$ Itecons - Institute for Research and Technological Development in Construction, Energy, Environmental and Sustainability Rua Pedro Hispano s/n., 3030-289 Coimbra, Portugal

${ }^{4}$ University of Brighton, Cockcroft Building, Lewes Road, BN2 4GJ, Brighton, United Kingdom

*Corresponding author: sresalati@brookes.ac.uk, +44 (0)1865 484190

The global market trend for Vacuum Insulation Panels (VIPs) is projecting a significant increase in their uptake in the construction sector. This is mainly due to the uniquely high-performance properties of the ultra-thin insulation materials. This uptake, however, can potentially be hindered by the VIPs' higher cost and environmental impacts when compared with conventional insulation materials. This paper, for the first time, presents a detailed evaluation of the environmental impact of the most common type of VIPs currently used in different applications with a focus on alternating the core material as the main contributing component to their footprint. Pyrogenic silica, glass fibre, expanded polystyrene, aerogel and a silica/sawdust hybrid core were analysed from cradle to gate. The study, on a comparative basis, demonstrates the sensitivity of the various environmental impact categories to the internal vacuum pressure and the subsequent thermal conductivity values. The results show a lower environmental impact for glass fibre and low density expanded polystyrene compared to the other alternatives. Pyrogenic silica, the most common core material, had the highest environmental impact out of the core materials considered. The higher environmental impacts of pyrogenic silica suggest that measures such as the recycling of the core material alongside the deployment of ecofriendlier manufacturing techniques should be considered if the material is to compete environmentally with the other alternative materials.

Keywords: Vacuum Insulation Panels, Life cycle Assessment, Environmental Impact, pyrogenic silica, Global Warming Potential.

\section{Introduction}

Among the various novel insulation materials currently emerging in the market, VIPs are the most promising solution offering the highest thermal insulating properties. This is evident in the fact that the global market for VIPs, estimated at US $\$ 7.2$ billion in the year 2020, is projected to reach US $\$ 10$ billion by 2027, growing at a compound annual growth rate (CAGR) of $4.8 \%$ (Global Industry Analysts, 
2020). VIPs feed into various end-user industries including construction, cooling and freezing devices, logistics and others, where construction is the most profitable end-user industry for the market. The 'Global Construction 2030' report by Oxford Economics forecasts that the volume of construction output will grow by $85 \%$ to $\$ 15.5$ trillion worldwide by 2030 . With VIPs offering several key advantages to the construction sector, such as providing increased indoor space and optimised land use due to the reduced thickness of building components. It is likely that the application of VIPs in the construction industry will increase even beyond the forecast values. With the rising number of building codes and standards requiring eco-friendly energy-efficiency measures, the demand for energy conserving materials in the construction sector is increasing. Insulation materials with lower associated environmental impacts relative to their thermal performance are crucial if the set targets are to be met.

Although VIPs offer very low thermal conductivity $(0.004-0.007 \mathrm{~W} /(\mathrm{m} . \mathrm{K}))$, up to 10 times better than other conventional thermal insulation materials (such as mineral wool, PUR, EPS and XPS), their relative embodied energy (EE) investment is higher. Resalati et al. (2020) demonstrated in their study that the EE of fumed-silica based VIPs $\left(\mathrm{GJ} / \mathrm{m}^{2}\right)$ for a given R-value (thermal resistance measured in $\mathrm{m}^{2} . \mathrm{K} / \mathrm{W}$ ) can also be up to 10 times (in the most extreme cases) greater than conventional insulation materials on a cradle to gate basis (Figure 1 ).

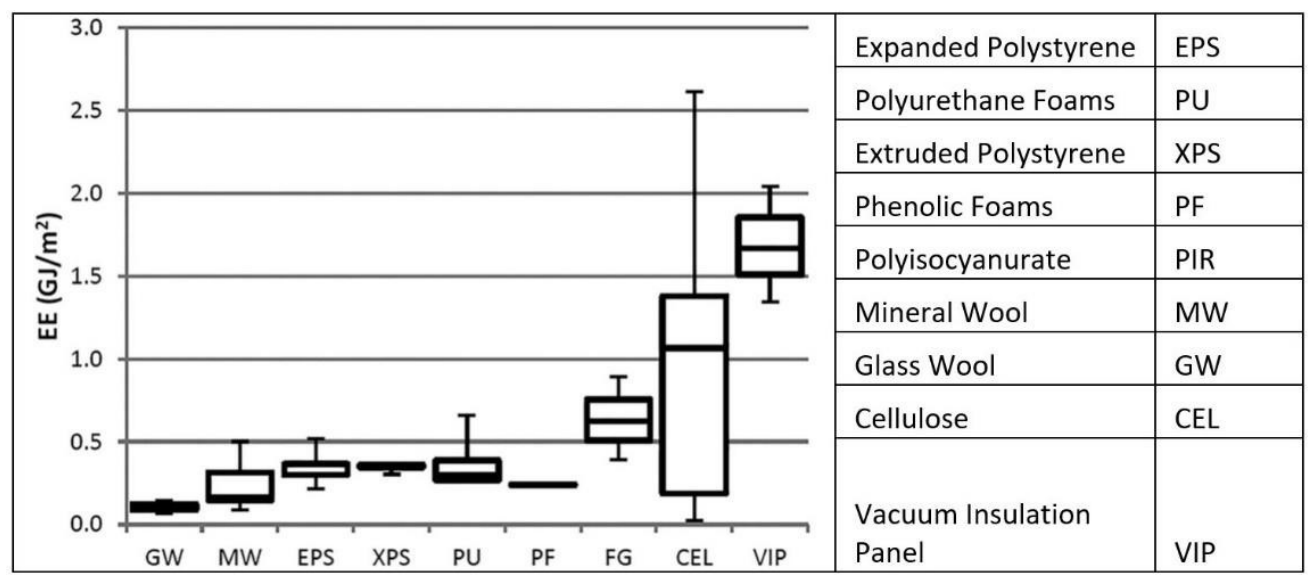

Figure 1: EE per unit area of different insulation materials for $\mathrm{R}=6.6 \mathrm{~m} 2 \mathrm{KW}-1$ (Reprinted with permission from Resalati et al. (2020))

The core material, barrier envelope, getter and desiccant are the main parts that make up a VIP (Figure 2) (Alam et al., 2011). The most commonly used core material for VIPs is made up of pyrogenic silica (Kalnæs and Jelle, 2014). It has been presented by studies such as the work of Schonhardt et al. (2003) and Karami et al. (2015) that the pyrogenic silica core is the key contributor to the environmental impact of VIPs, responsible for over $90 \%$ of the EE. The selection of the right core material is therefore of utmost importance as they are crucial to reducing the environmental impact of VIPs.

Different materials with varying thermal and structural properties have been studied in detail as the core materials for VIPs. These include different foams (polyurethane, expanded polystyrene and phenolic foam), powders (fumed or pyrogenic silica, silica aerogels and expanded perlite) and fibres (glass fibres) (Zach et al., 2019). However, a comparative assessment of the contribution of these core materials to the environmental impact of VIPs is still lacking.

This study therefore aims to present a comparative study of the environmental impact of the most commonly used core materials in VIPs. This, for the first time, enables the engaged stakeholders and end-users of VIPs to include the environmental performance in the decision-making process. 


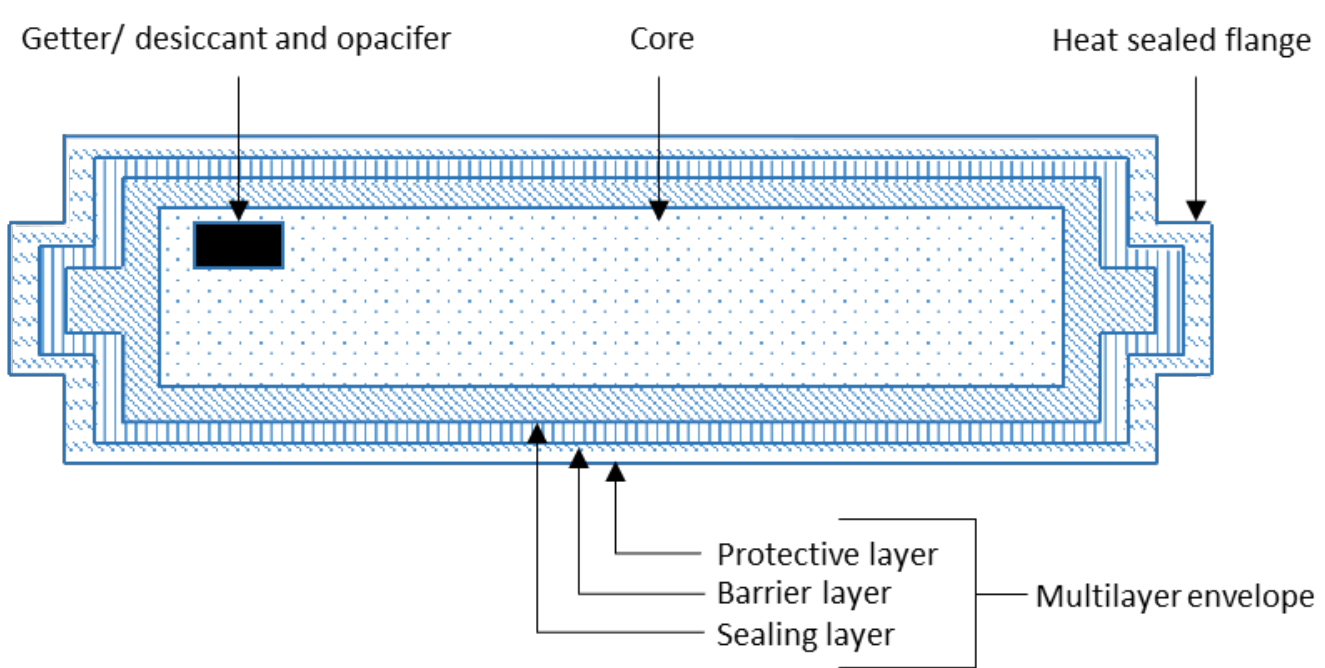

Figure 2: Schematic of a VIP (adapted from (Alam et al., 2011))

Comprehensive life cycle assessment (LCA) models were developed to analyse the potential environmental impacts of producing VIPs from raw material extraction through to the production gate. Pyrogenic silica, glass fibre, expanded polystyrene, aerogel and a hybrid core made up of a combination of sawdust ( $30 \%$ mass) and pyrogenic silica ( $55 \%$ mass) were assessed and characterised using the GaBi LCA software. Sensitivity analyses were conducted to quantify the effect of varying a) the thermal conductivity values in relation to the vacuum pressure on the environmental impact of the panels and $b$ ) the environmental burden of the different materials with reference to the available environmental product declarations (EPDs) and environmental impact assessment reports where available.

The paper consists of five sections, including this introduction. The physical properties and performance of the different types of VIP core materials are outlined in section two. The LCA methodology used is explained in detail in the materials and methods section with the results in the form of tables and graphs presented, analysed and discussed in section four. A conclusion section ends the paper by summarising the main findings of this study.

\section{Physical properties and performance of VIP core materials}

VIPs are usually manufactured consisting of a core material, an opacifier and laminate film (Karami et al., 2015). To prepare the panels, the constituent raw materials of the core are mixed, cut and pressed using a hydraulic press. They are then dried in an oven heated to between $60^{\circ} \mathrm{C}-150^{\circ} \mathrm{C}$ before being covered in a fabric. Laminated film is subsequently used to envelop the core which is then heat sealed after the air has been displaced from the product in a vacuum sealing chamber. VIP parts, if they are not damaged, can be recycled to a large extent. This is especially the case with the core material as after decommissioning, the core material can be prepared and used to manufacture another VIP if proven to be appropriate after the characterisation processes (Karami et al., 2015). The core material makes up the bulk of a typical VIPs mass $(>75 \%)$, therefore it is expected that the majority of the environmental impact of its manufacture will be attributed to the core material production.

The core material properties also dictate to a large extent the thermal and mechanical characteristics of the VIPs (Alam et al., 2011). Materials with small pores (10nm or less) are considered to be more suitable for VIPs as a higher vacuum pressure can be used to achieve the low thermal conductivities expected from VIPs. The structure of these pores also needs to be open for easy gas removal. Alongside these criteria, the material also has to be able to resist compression and be impermeable to infrared radiation (Baetens et al., 2010). 
Numerous materials have been commercially used as VIP cores including various powders (Fantucci et al., 2019), foams (Brunner et al., 2012), fibres (Di et al., 2013) and in some cases, a combination of materials (Li et al., 2016b). Each of the different core materials have their own pros and cons relative to the target application. The following sections provide an overview of the various core materials used to produce VIPs and detail their properties.

\section{Powders}

The most commonly used powders as core materials in VIPs include fumed or pyrogenic silica (Gonçalves et al., 2020), silica aerogels (Liang et al., 2017) and expanded perlite (Alam et al., 2014). Fumed silica is the most widely used core material in the building sector due to it being made up of entirely nano-pores that greatly affect the panel's thermal conductivity. It also shows a lower sensitivity to vacuum pressure fluctuations leading to a longer service life. Silica-based panels accounted for approximately half of the share of the global market in 2015. Silica also has the advantage of being non-toxic, fire resistant and recyclable (Kalnæs and Jelle, 2014). The material is produced through the pyrolysis of silicon tetrachloride at a very high temperature $\left(1500^{\circ} \mathrm{C}\right)$. Several studies have focused on the thermal characterisation of VIPs produced using silica as the core material indicating thermal conductivities between 0.0035 and $0.007 \mathrm{~W} /(\mathrm{m} . \mathrm{K}$ ) (Fantucci et al., 2019, Singh et al., 2015). Fumed silica has a density of between $180-200 \mathrm{Kg} / \mathrm{m}^{3}$ and it needs to be pressed under moderate load $(0.01-0.4 \mathrm{MPa})$ for it to be applied in VIPs.

Apart from fumed silica, aerogels are known to have particularly small pore diameters with a density in the range of $3-350 \mathrm{~kg} / \mathrm{m}^{3}$, with the higher densities typically associated with VIPs. Aerogel is manufactured in a two-step process. Acidic condensation or the sol-gel process is used to form the wet gel followed by wet gel drying using supercritical or ambient drying. The thermal conductivity of aerogel depending on the temperature is approximately between $0.01-0.03 \mathrm{~W} /(\mathrm{m} . \mathrm{K})$ and it has been seen to go as low as $0.004 \mathrm{~W} /(\mathrm{m} . \mathrm{K})$ at 5000 Par vacuum pressure (Alam et al., 2011) or less. It also has the advantage of being nonreactive and non-flammable but relatively expensive for practical economical application in the building sector (Baetens et al., 2010).

Expanded perlite has been shown to be less efficient than fumed silica and silica aerogel as a core material requiring vacuum pressure of below 10 Pa to achieve suitable VIP design thermal conductivity (Caps and Fricke, 2000). However, it can be used in combination with fumed silica to achieve good thermal conductivity at a comparatively higher pressure. The cost of fumed silica VIPs can potentially be reduced by $20 \%$ when expanded perlite, a lower cost material, is used in combination (Alam et al., 2014). Perlite is, however, 1.75 times denser than pyrogenic silica $\left(350 \mathrm{~kg} / \mathrm{m}^{3}\right.$ compared to $200 \mathrm{~kg} / \mathrm{m}^{3}$ ) with a higher thermal conductivity, hence a thicker perlite panel is required to achieve the same thermal performance. The weight of a finished square metre of perlite for a given thermal performance can exceed double that of a silica-based panel. Given that larger VIP panel sizes are preferable to reduce the thermal bridging effect, the greater mass per square metre means that perlite VIPs are deemed to be impractical.

In summary, for powders as core materials in general, a pressure of less than 10Pa at most is typically required relating to achievable pore sizes in the $\mathrm{nm}$ range with densities varying between 180 to 350 $\mathrm{kg} / \mathrm{m}^{3}$ depending on the material. Thermal conductivities for power type core materials range between 0.0035 and $0.007 \mathrm{~W} /(\mathrm{m} . \mathrm{K})$. The typical lifetime of powder core material VIPs is 15 years with the exception of pyrogenic silica with a lifetime of 60 years.

\section{Foams}

Polyurethane and expanded polystyrene are foams that have been deployed as core material in VIPs. They have a low density $\left(60-100 \mathrm{Kg} / \mathrm{m}^{3}\right)$ and relatively small pore size $(30-250 \mu \mathrm{m})$ enabling low thermal conductivity to be achieved (Alam et al., 2011). Polyurethane and expanded polystyrene are commonly used as standalone insulation materials with the first VIPs manufactured using polyurethane (Kalnæs and Jelle, 2014). This was because polyurethane has an open pore structure and the ability to withstand compressive force. However, due to its pore size being larger than that of both fumed silica and aerogel, it requires relatively lower pressure (less than $10 \mathrm{~Pa}$ ) to achieve the 
equivalent low thermal conductivity (Yang et al., 2012). Kim and their co-researchers investigated the use of phenolic foam as core material in VIPs (Kim et al., 2012). The material thermal conductivity was seen to be $0.005 \mathrm{~W} / \mathrm{m} . \mathrm{k}$ at a high level of vacuum. Additional support would be required to resist the load applied by atmospheric pressure because of its fragile structure. This could be in the form of circular pillars or covering plates and this would increase the thermal conductivity to those seen in polyurethane foam (0.005-0.007 W/mK). However, similar to other foams, it has a relatively short life when compared to pyrogenic silica and aerogel due to its large pore size (200-400 $\mu \mathrm{m})$. Insulation foams, although relatively cheap to manufacture, may not be fit for use in buildings due to their shorter lifespan.

For foams as core materials in general, a pressure of less than $10 \mathrm{~Pa}$ is typically required relating to achievable pore sizes on the order of $100 \mu \mathrm{m}$ with densities varying between 60 to $100 \mathrm{~kg} / \mathrm{m}^{3}$ depending on the material. Thermal conductivities for foam type core materials range between 0.005 and $0.007 \mathrm{~W} /(\mathrm{m} . \mathrm{K})$. The typical lifetime for foam core material VIPs is 15 years.

\section{Fibres}

Glass fibre offers a lower density $\left(250 \mathrm{~kg} / \mathrm{m}^{3}\right)$ and good thermal stability $\left(>1000{ }^{\circ} \mathrm{C}\right.$ ) compared with other core materials, therefore is effective as a core material for use in VIPs that are to be used in high temperature operations (Alam et al., 2011). The pores of the material are relatively large when compared with those of fumed silica and aerogel therefore, as with foams, it requires a low pressure (0.1 mbar) to achieve high thermal conductivity. Although glass fibre is relatively inexpensive, this is a hindrance to its application in buildings as research has estimated that the panel's lifespan would be 15 years (Di et al., 2013). VIPs using glass fibre as a core material are ideal for use in oven, furnaces and concentrated solar and fuel cell power plants.

Chen et al (2015) showed that the service life span of VIPs with glass fibre can be significantly increased by super stratifying the core material. This was achieved through the centrifugal spinneret blow process and it was able to attain a level of thermal conductivity $(0.00125 \mathrm{~W} /(\mathrm{m} . \mathrm{K}))$ up to two times better than conventional glass fibre $(0.00262 \mathrm{~W} /(\mathrm{m} . \mathrm{K}))$. The pore size $(3 \mu \mathrm{m})$ was also measured to be $70 \%$ smaller than the average $10 \mu \mathrm{m}$ for glass fibre (Chen et al., 2015).

Researchers have also been able to investigate the use of melamine-formaldehyde and wood fibres as VIP core materials. Nemanic and Zumer showed that the melamine-formaldehyde fibre had high thermal stability with a pore diameter below $5 \mu \mathrm{m}$ (Nemanič and Žumer, 2015). This enables the novel fibre to have thermal insulating properties $(0.0023 \mathrm{~W} /(\mathrm{m} . \mathrm{K}))$ similar to conventional glass fibre. Wood fibre, with an average pore size of $112.8 \mu \mathrm{m}$ and thermal conductivity of $0.0094 \mathrm{~W} /(\mathrm{m} . \mathrm{K})$, was not found to compete favourably with conventional glass fibre VIPs (Wang et al., 2019).

In summary regarding fibre as a core material in general, a pressure of less than $10 \mathrm{~Pa}$ is typically required relating to achievable pore sizes of 1 to $10 \mu \mathrm{m}$ with densities around $250 \mathrm{~kg} / \mathrm{m}^{3}$ depending on the material. Thermal conductivities for fibre type core materials range between 0.001 and 0.009 $\mathrm{W} /(\mathrm{m} . \mathrm{K})$. The typical lifetime for fibre core material VIPs is 15 years.

\section{Hybrids and other core materials}

Hybrid cores made up of a combination of suitable materials have been proposed by researchers to improve VIP lifespan and cost. This is usually a combination of conventional materials such as pyrogenic silica or glass fibre with other appropriate materials.

Researchers have been able to successfully combine pyrogenic silica with expanded perlite (Alam et al., 2014), glass fibre (Singh et al., 2015), hollow glass microfiber (Li et al., 2016b), diatomaceous earth (Chang et al., 2016), rice husk ash (Li et al., 2016a) and expanded cork (Zhuang et al., 2017). This has resulted in VIP cores with densities of between 114 and $290 \mathrm{Kg} / \mathrm{m}^{3}$ with different levels of porosity and thermal conductivity. Singh and their co-researchers were able to achieve a particularly low thermal conductivity $(0.0037 \mathrm{~W} /(\mathrm{m} . \mathrm{K}))$ that could rival the commercially-available VIPs using a hybrid core comprising of $75 \%$ pyrogenic silica, $20 \%$ carbon black (opacifier) and $5 \%$ glass fibre (Singh et al., 2015). Comparing this with the results of other studies, the particularly high percentage of pyrogenic 
silica could explain its superior performance. Pyrogenic silica hybrid cores have been shown to have thermal conductivity between 0.0037 and $0.0103 \mathrm{~W} /(\mathrm{m} . \mathrm{K})$ according to Chang et al (2016) who used a low $30 \%$ pyrogenic silica in their hybrid core.

Novel alternative core materials have also been proposed to reduce the reliance on pyrogenic silica VIP for application in buildings. Tetlow and their co-researchers investigated the use of cellulosiccrystals as a core material due to its similar physical structure to pyrogenic silica and biodegradability (Tetlow et al., 2017). Thermal conductivity tests revealed that despite its positive physical and environmental properties, it could not rival pyrogenic silica's thermal properties. Alam and Singh (2019) proposed the use of sawdust powder in combination with fumed silica in the VIP core for ecofriendly VIPs. The use of lightweight concrete have also been proposed to improve material strength and the overall cost of the VIP core material (Chung et al., 2020). Thermal conductivities in the region of $0.049-0.1086 \mathrm{~W} /(\mathrm{m} . \mathrm{K})$ were achieved, indicating that concrete may not be suitable for use in buildings needing a high level of insulation.

\section{Materials and Methods}

The LCA investigation in this paper follows the methodological framework of ISO14040:2006 and will cover the goal and scope definition, inventory analysis, impact assessment and interpretation of the results. The paper will also reference the EN 15978:2011 and EN 15804:2012 European standards (European Commitee, 2011, CEN, 2012) detailing the system boundaries for the LCA of building materials.

Table 1 summarises the different classifications of the life cycle stages of building or construction materials based on the EN 15978 and EN 15804 European standards. It indicates that the system boundaries can either be cradle to gate, cradle to grave or cradle to cradle. Cradle to gate includes the extraction, processing and transportation of raw materials while cradle to grave contain these steps alongside the transportation of the final product, distribution, assembly, use, maintenance and final disposal. Cradle to cradle is unique as it provides scope for the reuse, recovery or recycling of the product. According to the literature, having different system boundaries can add to the complexity of LCA studies and their place compared with other existing LCA studies (Moncaster and Song, 2012). LCA methodologies are data-driven approaches that rely on the availability of high-quality accurate data (Jusselme et al., 2018) (Azzouz et al., 2017) but finding reliable data has been an issue for LCA practitioners (De Wolf et al., 2017). The literature has associated this issue with several factors including confidentiality and IP management issues for manufacturers, in addition to the time intensiveness of generating reliable data and the different methodological approaches involved in the data treatment (Lotteau et al., 2015; Soust-Verdaguer et al., 2016). In order to reduce the uncertainty of the results, a cradle to gate approach has been adopted in this study as there is less uncertainty associated with the data relating to the VIP fabrication process. A cradle to gate (including modules A1-A3 as referenced in EN 15804) system boundary includes the environmental impacts of manufacturing the VIPs and their associated core materials from the extraction of raw material through to the final product assembly.

EN15804 requires the reporting of energy inputs as primary energy and the categories describing resource use as follows:

- The use of renewable primary energy excluding renewable primary energy resources used as raw materials.

- The use of non-renewable primary energy excluding non-renewable primary energy resources used as raw materials.

This was also demonstrated in the work of Dixit, Fernández-Solís, Lavy, and Culp (2012) that stated that not including renewable energy in the definition of EE could lead to errors as high as $40 \%$ when reporting EE. The results in this study are therefore defined as the primary energy used for the production of the insulation material from cradle to factory gate (including both renewable and nonrenewable primary energy). 
Table 1: Classification of the life cycle stages in the LCA of construction materials based on the EN 15978 and EN 15804 European standards(Pargana et al., 2014)

\begin{tabular}{|c|c|c|}
\hline $\begin{array}{l}\text { LCA } \\
\text { boundaries }\end{array}$ & Life cycle stages & Description \\
\hline \multirow[t]{3}{*}{ Cradle to gate } & \multirow[t]{3}{*}{$\begin{array}{l}\text { Product stage (A1- } \\
\text { A3) }\end{array}$} & $\begin{array}{l}\text { A1 Raw material supply, including processing of secondary } \\
\text { material input }\end{array}$ \\
\hline & & $\begin{array}{l}\text { A2 Transportation of the raw material and secondary } \\
\text { material to the manufacturer }\end{array}$ \\
\hline & & $\begin{array}{l}\text { A3 Manufacture of the construction products and all } \\
\text { upstream processes from cradle to gate }\end{array}$ \\
\hline \multirow{13}{*}{$\begin{array}{l}\text { Cradle to } \\
\text { cradle, Cradle } \\
\text { to grave, gate } \\
\text { to grave }\end{array}$} & \multirow[t]{2}{*}{$\begin{array}{l}\text { Construction stage } \\
\text { (A4-A5) }\end{array}$} & $\begin{array}{l}\text { A4 Transportation of the construction products to the } \\
\text { building site }\end{array}$ \\
\hline & & A5 Installation in building \\
\hline & \multirow{5}{*}{$\begin{array}{l}\text { Use Stage, related } \\
\text { to building fabric } \\
\text { (B1-B5) }\end{array}$} & B1 Use of the installed product \\
\hline & & B2 Maintenance of the product \\
\hline & & B3 Repair of the product \\
\hline & & B4 Replacement of the product \\
\hline & & B5 Replacement of the product \\
\hline & \multirow{2}{*}{$\begin{array}{l}\text { Use Stage, related } \\
\text { to operation of } \\
\text { building (B6-B7) }\end{array}$} & B6 Operational energy \\
\hline & & B7 Operational water use \\
\hline & \multirow{4}{*}{$\begin{array}{l}\text { End of life stage } \\
\text { (C1-C4) }\end{array}$} & C1 Demolition of the building/ building product \\
\hline & & $\begin{array}{l}\text { C2 Transportation of the demolition waste comprising the } \\
\text { transportation of the end of life construction product to a } \\
\text { waste processing facility }\end{array}$ \\
\hline & & $\begin{array}{l}\text { C3 Waste processing operations for reuse, recovery or } \\
\text { recycling }\end{array}$ \\
\hline & & C4 Final disposal of the end of life construction product \\
\hline & $\begin{array}{l}\text { Benefits and load } \\
\text { beyond the system } \\
\text { boundary }\end{array}$ & $\begin{array}{l}\text { D Reuse/recovery/recycling potential evaluated as net } \\
\text { impacts and benefits }\end{array}$ \\
\hline
\end{tabular}

\subsection{Goal and scope definition}

The main goal of this study was to evaluate and compare the environmental impacts of five different VIP core materials to assist the engaged stakeholders and end users of the products in their decisionmaking process. The functional unit was the amount of insulating core material needed to achieve a U-value of $0.27 \mathrm{~W} / \mathrm{m}^{2} \mathrm{~K}$ (R-value of $3.7 \mathrm{~m}^{2} \mathrm{~K} / \mathrm{W}$ ) in a $1 \mathrm{~m}^{2}$ of panel. The target U-value is equivalent to the performance of $1 \mathrm{~m}^{2}$ of a $20 \mathrm{~mm}$ thick pyrogenic silica-based VIP with thermal bridging and aging values considered.

The core material is pressed and under compressive strain when used in VIP. Therefore the thermal conductivity at atmospheric pressure could change. The measured thermal conductivities under vacuum were collected from the literature. An LCA model of a typical VIP with a pyrogenic silica core was modelled as the baseline followed by the alternative core materials introduced to the model for comparative purposes. Table 2 shows the inventory used for this analysis (data provided by a VIP manufacturer). 
Table 2: Inventory data selected to model the environmental impact of a typical VIP

\begin{tabular}{|l|l|l|l|}
\hline VIP Part & Raw material & Quantity & Unit \\
\hline Core material & Pyrogenic silica & 3.4 & $\mathrm{Kg}$ \\
\hline Laminate film & Tri-laminate film & 0.3 & $\mathrm{Kg}$ \\
\hline Others & Magnetite & 0.6 & $\mathrm{Kg}$ \\
\hline Fleece for sensor & Fleece for sensor & 0.00015 & $\mathrm{Kg}$ \\
\hline & Metal chip for sensor & 0.003 & $\mathrm{Kg}$ \\
\hline & Polyester Fibre Fleece & 0.15 & $\mathrm{Kg}$ \\
\hline Electricity & & 0.36 & $\mathrm{GJ}$ \\
\hline
\end{tabular}

Table 3 shows the experimentally determined thermal conductivity at $100 \mathrm{~Pa}$ alongside the characteristics of each of the five different core materials required to achieve the functional unit. The properties of pyrogenic silica, glass fibre and expanded polystyrene were taken from the work of (Alam et al., 2017), (Di et al., 2013) and (Wong and Hung, 2008) respectively while the centre of panel thermal conductivity of the hybrid core was measured in the laboratory by Alam and Singh (2019) using a heat flow meter based on ASTM C518.

Table 3: Characteristics of the VIP core materials required to achieve a U-value of $0.27 \mathrm{~W} / \mathrm{m}^{2} \mathrm{~K}$

\begin{tabular}{|c|c|c|c|c|c|}
\hline Core Material & $\begin{array}{l}\text { Density of } \\
\text { Core } \\
\text { Material } \\
\left(\mathrm{Kg} / \mathrm{m}^{3}\right)\end{array}$ & $\begin{array}{l}\text { Thermal } \\
\text { Conductivity } \\
\text { at } 100 \mathrm{~Pa} \\
(\mathrm{~W} /(\mathrm{m} . \mathrm{K}))\end{array}$ & $\begin{array}{l}\text { Thickness } \\
\text { (mm) }\end{array}$ & $\begin{array}{l}\text { Weight } \\
\text { (Kg) }\end{array}$ & Reference \\
\hline Pyrogenic Silica & 180 & 0.0043 & 20 & 3.6 & (Alam et al., 2017) \\
\hline Glass fibre & 250 & $0.0062 *$ & 22.96 & 4.94 & (Di et al., 2013) \\
\hline $\begin{array}{l}\text { Expanded } \\
\text { Polystyrene }\end{array}$ & 40 & 0.01 & 37.037 & 1.48 & $\begin{array}{l}\text { (Wong and Hung, } \\
\text { 2008) }\end{array}$ \\
\hline Aerogel & 114 & 0.0065 & 24.07 & 2.74 & (Liang et al., 2017) \\
\hline $\begin{array}{l}\text { Hybrid Sawdust } \\
\text { (30\% mass) and } \\
\text { pyrogenic silica } \\
\text { (55\% mass) }\end{array}$ & 286 & 0.00552 & 20.44 & $\begin{array}{l}1.31 ; 2.40 \\
* *\end{array}$ & \\
\hline
\end{tabular}

*The glass fibre thermal conductivity at 100Pa vacuum pressure (Section 3.3 investigates the sensitivity of these results according to the vacuum pressure).

**Excluding SiC

The system boundaries in the LCA studies show the unit operations that are to be included in the assessment. The system boundary included the energy and materials needed for the production, transportation and storage of the required raw materials as well as the energy needed to manufacture the different core materials.

\subsection{Life cycle inventory and Impact assessment}

The database of the GaBi LCA software was used to obtain the background data (raw material and energy) needed for the modelling of the different core materials. Table 5 demonstrates the life cycle inventory $(\mathrm{LCl})$ data selected for the LCA models summarising the raw materials and processes used. The data for the glass fibre and expanded polystyrene were taken directly from the database of $\mathrm{GaBi}$.

The availability of data on the production of pyrogenic silica is limited as the relevant suppliers consider the data to be confidential. Therefore, the production of synthetic amorphous pyrogenic silica was modelled using average industry data provided by CEFIC-ASASP (Source: European Commission, Integrated Pollution Prevention and Control, Reference Document on Best Available Techniques for 
the Manufacture of Large Volume Inorganic Chemicals - Solids and Others industry. July 2007) (European Commission, 2007). According to CEFIC-ASASP, silane, hydrogen and air are required for the production of pyrogenic silica. Energy is consumed to heat the hydrogen gas, combust the air and evaporate the chlorosilanes (and/or methylchlorosilanes) as well as to remove residual hydrochloride from the silica surface. Table 4 demonstrates in detail the energy consumed to produce $1000 \mathrm{~kg}$ of pyrogenic silica powder with the energy for hydrochloric acid $(\mathrm{HCl})$ recovery included. This was assumed to be the inventory data for the production of the core materials and it has been used in this paper to calculate the environmental impacts.

Table 4: Production of pyrogenic silica (1000Kg), (European Commission, 2007)

\begin{tabular}{|l|l|l|}
\hline Inputs & Quantity & Unit \\
\hline Tetrachlorosilane & 2700 & $\mathrm{Kg}$ \\
\hline Hydrogen & $\sim 1000$ & $\mathrm{Nm}^{3}$ \\
\hline Energy use (electricity) & 16.5 & $\mathrm{GJ}$ \\
\hline
\end{tabular}

The electricity and natural gas for the production of the core material was assumed to be supplied from an average of 28 countries in the European Union according to the database of GaBi. For the modelling of the hybrid core material, it was assumed that the sawdust was obtained from wood processing scraps, hence no environmental impact from this was accounted for in the analysis. The sawdust is primarily used to reduce the amount of pyrogenic silica used as a core material while still achieving the same thermal performance. The environmental impact of aerogel accounting for the quantity of the material $(2.74 \mathrm{Kg}$, see respectively while the centre of panel thermal conductivity of the hybrid core was measured in the laboratory by Alam and Singh (2019) using a heat flow meter based on ASTM C518.

Table 3) needed to achieve the functional unit was drawn from the relevant Environmental Product Declarations (Aspen Aerogels Inc., 2015).

Table 5: $\mathrm{LCl}$ data selected in order to model the environmental impact of the different core materials

\begin{tabular}{|l|l|l|l|}
\hline Core Material & Raw material; Process Chosen & Quantity & Unit \\
\hline Pyrogenic silica & Tetrachlorosilane & 9.18 & $\mathrm{Kg}$ \\
\cline { 2 - 4 } & Hydrogen & 3.40 & $\mathrm{Nm}^{3}$ \\
\cline { 2 - 4 } & Electricity & 0.0561 & $\mathrm{GJ}$ \\
\hline Glass fibre & $\begin{array}{l}\text { Glass fibre, production mix, at } \\
\text { plant (EU-28) }\end{array}$ & 4.94 & $\mathrm{Kg}$ \\
\hline Polystyrene & $\begin{array}{l}\text { Expanded Polystyrene (PS30) } \\
\text { (EN15804 A1-A3), production mix, } \\
\text { at plant (EU-28) }\end{array}$ & 1.48 & $\mathrm{Kg}$ \\
\hline Hybrid & Sawdust & 1.30 & $\mathrm{Kg}$ \\
\cline { 2 - 4 } & Pyrogenic Silica & 2.39 & $\mathrm{Kg}$ \\
\hline Aerogel & Aerogel & 2.74 & $\mathrm{Kg}$ \\
\hline
\end{tabular}


The analysis is presented based on the CML 2001 characterisation factors as required by the EN15804 European standards. The CML 2001 characterisation method addresses the early stages in the causeeffect chain in order to limit uncertainties. The results are grouped in seven midpoint environmental impact categories (CEN, 2012) including global warming potential (GWP), ozone depletion potential (ODP), acidification potential (AP), eutrophication potential (EP), photochemical ozone creation potential (POCP), abiotic depletion potential (ADP) and water resource depletion (WRD). These were selected alongside two other environmental impact categories, specifically primary energy nonrenewable resource (PENRT) and primary energy renewable resource (PERT) as seen in European EPDs. The contribution of different materials and products to these impact categories is mainly affected by their specific composition including their renewable or non-renewable nature, chemical properties, energy and water demand during extraction and post-extraction processing and their end of life characteristics. The manufacturing stages as well as the use phase could also contribute to the materials' environmental performance. The nine environmental impact categories (GWP, ODP, AP, EP, POCP, ADP, WRD, PENRT and PERT) used in this study allow for the comparison of the results obtained here with the LCAs and EPDs of the VIP core materials found in the literature or as part of studies to be conducted in the future.

\section{Results and discussion}

\subsection{VIPs with a pyrogenic silica core}

A life cycle assessment of a conventional silica-based VIP was conducted in order to determine the role of its individual components related to the environmental impact of VIPs (Table 5). This was used as the base-case for the analysis. The results have been presented using the identified environmental impact categories.

The core material mass of the VIPs considered in this study makes up over $75 \%$ of the total mass of the VIP. As expected, it was observed that for all nine selected impact categories, the pyrogenic silica core had the highest environmental impact compared to the other components of the panel (over $60 \%$ of any selected impact category). The core material was followed by the environmental impact

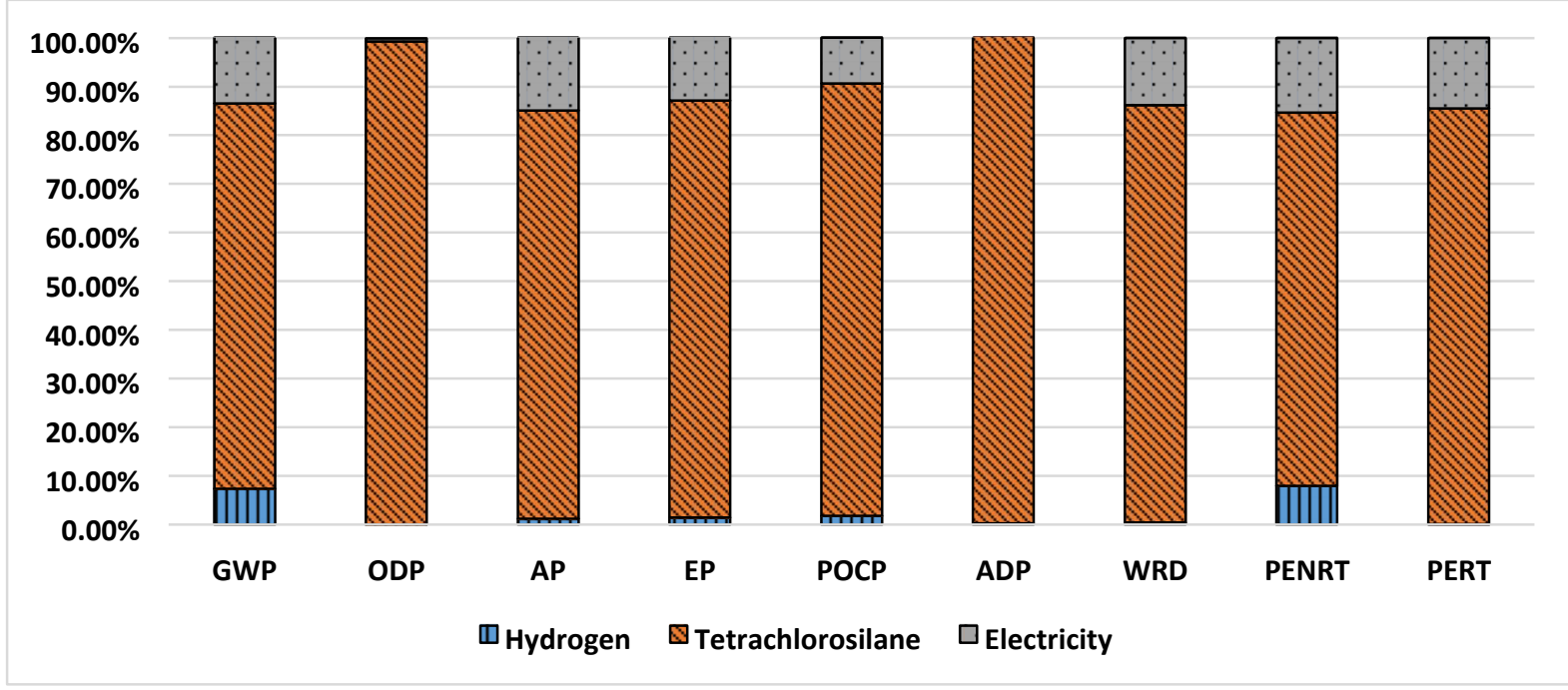

Figure 2: Distribution of the environmental impact for the raw materials used in producing pyrogenic silica

\subsection{Comparison of the alternative core materials with pyrogenic silica-based panels}

The same nine midpoint indicators were used to compare the pyrogenic silica, glass fibre, expanded polystyrene, aerogel and the hybrid core at a vacuum pressure kept at $100 \mathrm{~Pa}$. Figure 3 displays the results relative to the maximum value in each of the selected impact categories. Pyrogenic silica was observed to have the highest impact in seven of the selected impact categories (GWP, AP, EP, ADP, WRD, PENRT and PERT) while expanded polystyrene had the lowest impact in eight (GWP, ODP, AP, EP, ADP, WRD, PENRT and PERT). Expanded polystyrene was always $20 \%$ lower than the maximum in 
these categories except in the POCP impact category where it had the highest impact due to the emissions of comparatively more potent non-methane volatile organic compounds. The hybrid core had the second highest impact in six of the nine selected impact categories (GWP, AP, EP, WRD, PENRT and PERT). It was always $75 \%$ lower than the maximum in these categories with pyrogenic silica always having the highest environmental burden. Looking at the ODP impact category, the core material with the highest impact was aerogel followed by glass fibre. The relatively lower values for the expanded polystyrene can be associated with the lower density of the material used ( 3 to 7 times lower than the other materials compared in this paper).

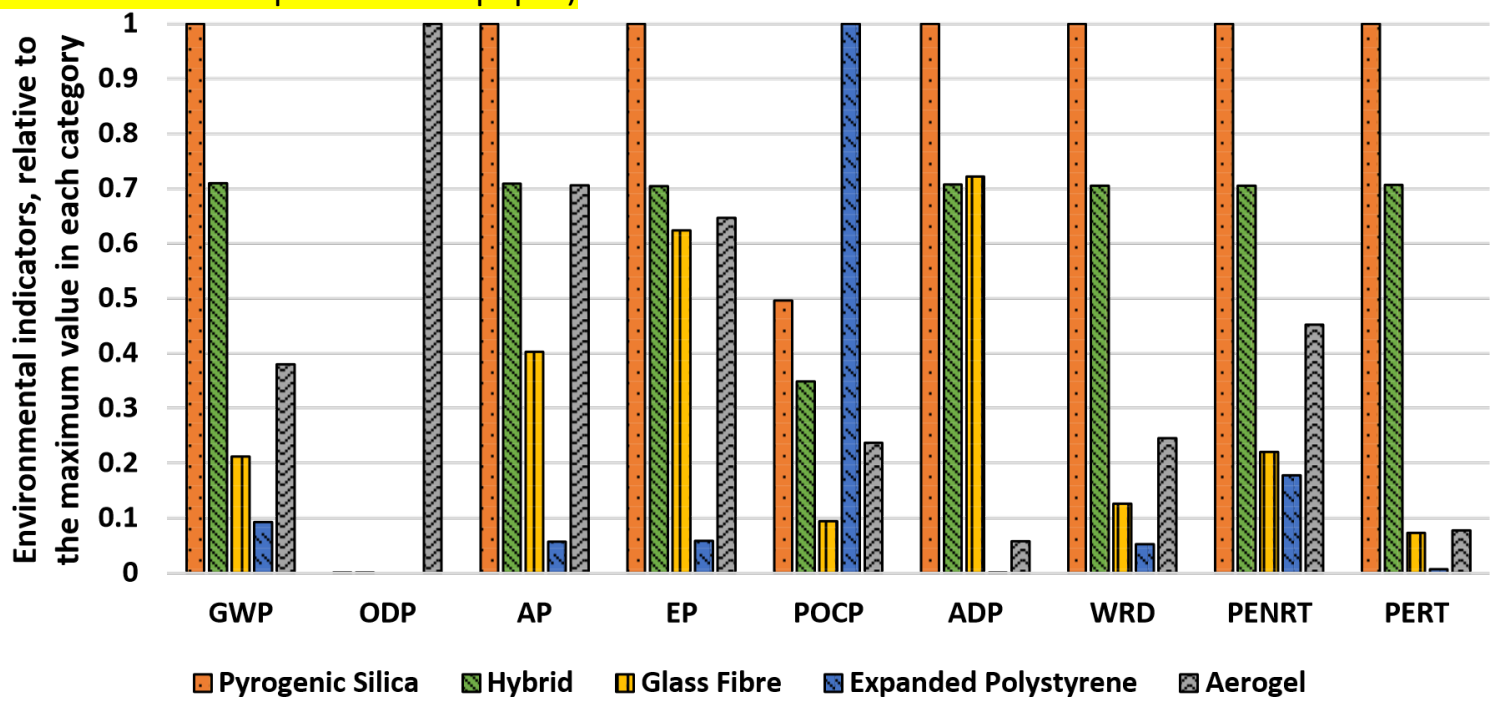

Figure 3: Life cycle impact assessment results for pyrogenic silica, glass fibre, expanded polystyrene, aerogel and hybrid (sawdust and pyrogenic silica) VIP core material (Results are displayed relative to the maximum)

Figure 4 shows the contribution of the different core materials toward the overall impact of the VIP. Pyrogenic silica, as mentioned earlier, contributed the most in all of the selected impact categories compared to the other components of the panel. Although pyrogenic silica has advantages such as its non-combustibility, recyclability (Kalnæs and Jelle, 2014) and lower sensitivity to vacuum pressure changes, it has a good deal of undesirable impacts on the environment when compared to the other core materials analysed, especially when virgin pyrogenic silica is used. The hybrid core material made up of sawdust ( $30 \%$ mass) and pyrogenic silica ( $55 \%$ mass) follows a similar trend of results at a lower rate. However, when the pyrogenic silica core is replaced with aerogel, there is a $>20 \%$ reduction in the cores contribution in the ADP, WRD and PERT impact categories. Electricity consumption and laminate film were seen to contribute the highest in the PERT and ADP impact categories respectively unlike the results obtained for the pyrogenic silica VIP where the core had the highest impact in all categories. Looking at the glass fibre VIP, a $>20 \%$ reduction was seen in the contribution of the core material in five of the selected impact categories (GWP, POCP, WRD, PENRT and PERT). Replacing pyrogenic silica with expanded polystyrene records a $>20 \%$ reduction in all of the selected impact categories except for POCP where there was $4 \%$ increase. The increase in the POCP impact category was because a $1 \mathrm{~m}^{2}$ expanded polystyrene VIP achieving a U-value of $0.27 \mathrm{~W} /\left(\mathrm{m}^{2} \mathrm{~K}\right)$ requires almost twice the amount of laminate film as the pyrogenic silica VIP. 


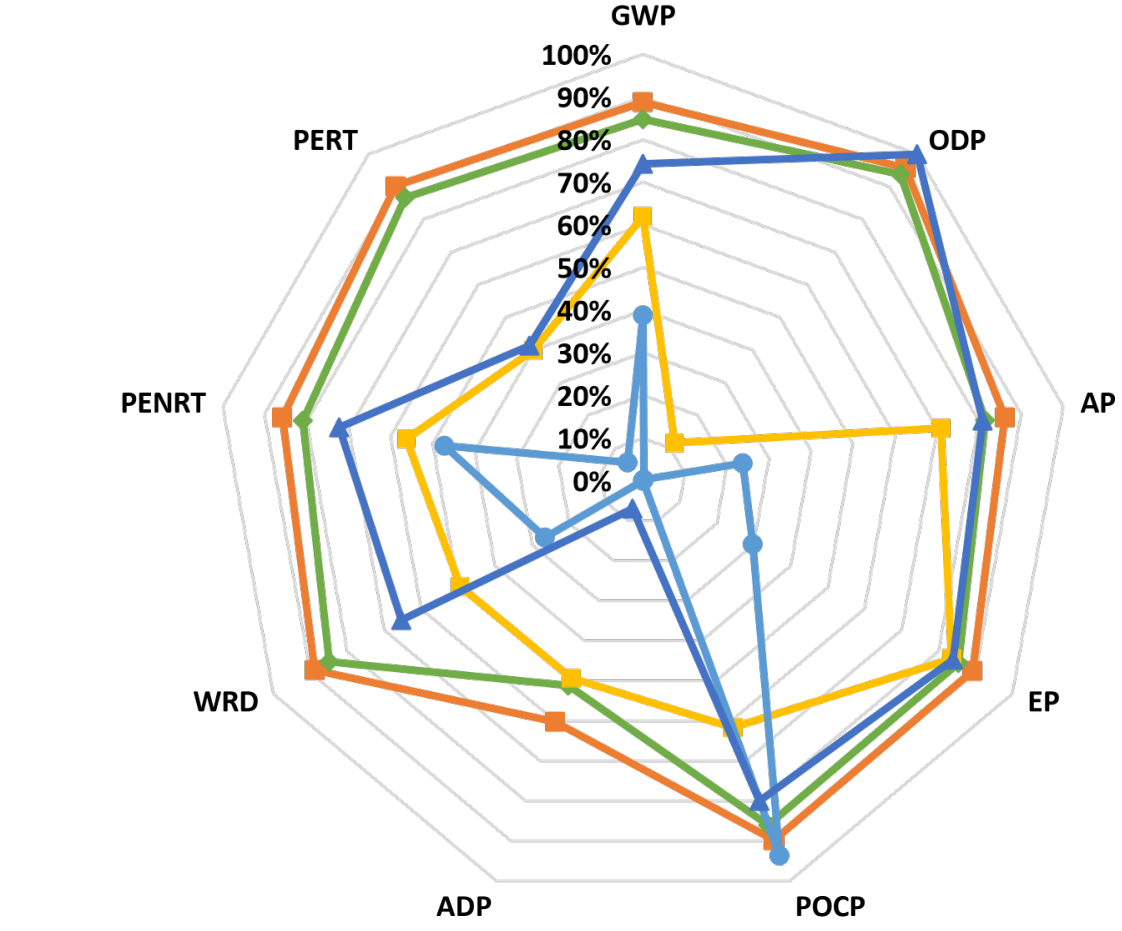

$\neg$ Pyrogenic Silica $\sim$ Hybrid - Glass Fibre $\longrightarrow$ Expanded Polystyrene $\longrightarrow$ Aerogel

Figure 4: Contribution of the core material to the overall environmental impact of the VIP

Table 6 indicates that for the expanded polystyrene VIP, the electricity consumption contributed the highest in five of the selected impact categories (GWP, AP, EP, WRD and PERT). This core material, unlike the pyrogenic silica VIP, contributed the highest in only the POCP and PENRT impact categories. It was also found to be the second highest in three categories (GWP, AP and EP) and the lowest in one (ADP) impact category.

Table 6: Life cycle impact assessment results for the expanded polystyrene VIP at a U-value of $0.27 \mathrm{~W} / \mathrm{m}^{2} \mathrm{~K}$

\begin{tabular}{|l|l|l|l|l|l|}
\hline $\begin{array}{l}\text { Impact } \\
\text { Category }\end{array}$ & Unit & Core material & Electricity & Laminate film & $\begin{array}{l}\text { All other } \\
\text { materials }\end{array}$ \\
\hline GWP & $\mathrm{kg} \mathrm{CO}_{2}$ eq & 4.11 & 4.18 & 1.83 & 0.461 \\
\hline ODP & $\mathrm{kg} \mathrm{R}-11$ eq & $8.04 \mathrm{E}-15$ & $1.17 \mathrm{E}-13$ & $2.06 \mathrm{E}-12$ & $2.69 \mathrm{E}-15$ \\
\hline $\mathrm{AP}$ & $\mathrm{kg} \mathrm{SO}_{2}$ eq & 0.00649 & 0.0118 & 0.00554 & 0.00341 \\
\hline $\mathrm{EP}$ & $\mathrm{kg} \mathrm{PO}_{4}$ eq & 0.000739 & 0.00111 & $4.94 \mathrm{E}-04$ & 0.000133 \\
\hline POCP & $\mathrm{kg} \mathrm{C}_{2} \mathrm{H}_{4}$ & 0.0236 & 0.00075 & 0.000602 & 0.000259 \\
\hline ADP & $\mathrm{kg} \mathrm{Sb}$ eq $^{3}$ & 0.000000618 & 0.00000133 & $1.16 \mathrm{E}-06$ & 0.000126 \\
\hline WRD & $\mathrm{m}^{3}$ water eq & 0.0201 & 0.0357 & 0.0174 & 0.00238 \\
\hline PENRT & $\mathrm{MJ}$ & 129 & 75.2 & 51.4 & 17 \\
\hline PERT & $\mathrm{MJ}$ & 2.11 & 30.3 & 4.81 & 0.722 \\
\hline
\end{tabular}

The results show that the lower density of expanded polystyrene allows it to reduce the contribution of the core material according to the overall impact of the VIP. This, alongside the use of renewable energy for electricity generation, could make the expanded polystyrene VIP attractive in theory. The associated technical hindrances need to be resolved first to allow for this relatively cheap material to compete with the other core materials on an environmental impact basis. It must also be noted that in order to maintain the acceptable low thermal conductivity of the EPS foams as the core material, relatively low gas pressures are required (10Pa and lower) (Alotaibi and Riffat, 2013). 


\subsection{Sensitivity Analysis}

4.3.1. Thermal conductivity values relative to the internal vacuum pressure

The sensitivity of the LCA results related to the internal pressure of the VIPs were explored by varying the vacuum pressure between 0.1 and $100000 \mathrm{~Pa}$. Figure 5 demonstrates the relationship between the thermal conductivity of the panels and the internal pressure with the thermal conductivity increasing when the pressure inside the VIP is increased.

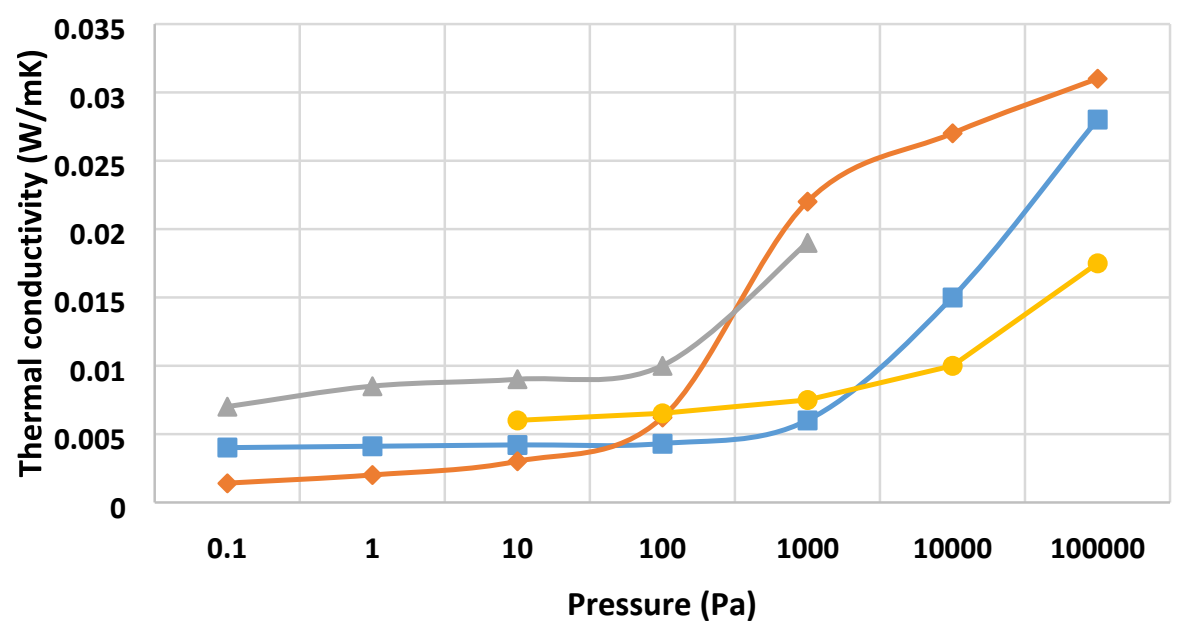

$\longrightarrow$ Pyrogenic Silica $\longrightarrow$ Glass Fibre $\longrightarrow$ Expanded Polystyrene - - Aerogel

Figure 5: Thermal conductivity of the pyrogenic silica, glass fibre, expanded polystyrene and aerogel VIP core materials as a function of internal pressure (data obtained from (Di et al., 2013, Di et al., 2014, Wong and Hung, 2008, Liang et al., 2017, Chen et al., 2015))

Table 7 compiles and demonstrates the changes to the environmental burden when the internal pressure is adjusted. The associated thermal conductivity for each pressure point as found in the literature (Figure 5) was used to calculate the required mass of material needed to achieve the target thermal performance of the VIPs (U-value $0.27 \mathrm{~W} / \mathrm{m}^{2} \mathrm{~K}$ ). It can be observed that an increase in pressure leads to a subsequent increase in the environmental burden of all impact categories selected as expected.

Using GWP and EE as environmental proxies demonstrated that the environmental burden associated with pyrogenic silica across the range of different vacuum pressures outweighs the other alternative core materials. The results presented in the previous section show there to be a better environmental performance for polystyrene on a cradle to gate basis mainly due to the lower density of the material used. Glass fibre environmentally outperforms the polystyrene core for vacuum pressures lower than $100 \mathrm{~Pa}$ and $10 \mathrm{~Pa}$ for EE and GWP respectively. This is the threshold for which the lower environmental impact of high density glass fibre outweighs the higher environmental impact of the lower density polystyrene core. Taking the other impact categories into account, glass fibre only demonstrates a better environmental performance for POCP (across the pressure range) and WRD (for vacuum pressures lower than 10Pa) while the polystyrene performs better in the ODP, AP, EP and ADP categories.

Table 7: LCA results for the pyrogenic silica, glass fibre, expanded polystyrene and aerogel for the different VIP internal pressures

\begin{tabular}{|l|l|l|l|l|l|l|l|l|l|l|}
\hline Core Material & $\begin{array}{l}\text { Impact } \\
\text { Category }\end{array}$ & Unit & \multicolumn{6}{|c|}{ Pressure (Pa) } \\
\hline
\end{tabular}




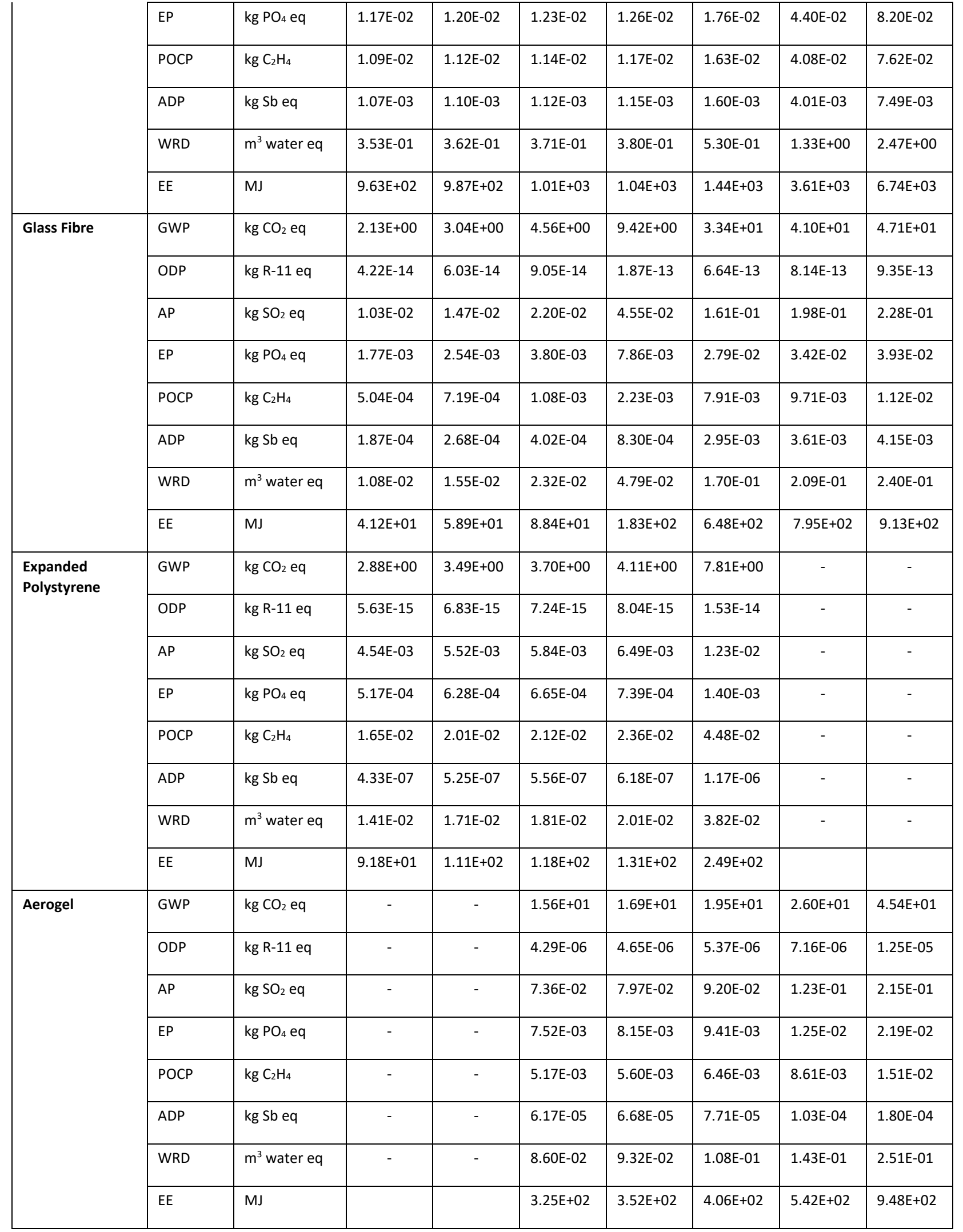

\subsubsection{Environmental Product Declaration Comparison}

The environmental product declarations (EPDs) for glass fibre and expanded polystyrene were selected for comparison with the results modelled here. Due to the lack of published EPDs and verified environmental assessment reports, the remaining core materials were not considered. A comparative assessment was done by determining the environmental impact of replacing the modelled core material with that from the EPDs. The weight of the materials required for the VIP to achieve the status of functional unit $\left(0.27 \mathrm{~W} /\left(\mathrm{m}^{2} \mathrm{~K}\right)\right)$ were $4.94 \mathrm{~kg}$ and $1.48 \mathrm{~kg}$ for the glass fibre and expanded polystyrene respectively (see Table 3 ). 
The impact assessment results from the selected EPDs were used to compare those obtained by the model. Table 8 shows the results of this comparison using GWP and EE as proxies. EE is the total energy used for the production of the core materials and it is the sum of the PENRT and PERT impact categories. It should be noted that due to the core material being a pressurised design, the thermal conductivity would change. Informed by the literature, the thermal conductivity of the glass fibre and expanded polystyrene when used in VIP were $0.0062 \mathrm{~W} /(\mathrm{m} . \mathrm{K})$ and $0.009 \mathrm{~W} /(\mathrm{m} . \mathrm{K})$ respectively at $100 \mathrm{~Pa}$ vacuum pressure.

Table 8: GWP and EE comparison of modelled glass fibre and expanded polystyrene with literature

\begin{tabular}{|c|c|c|c|c|c|c|}
\hline $\begin{array}{l}\text { Core } \\
\text { material }\end{array}$ & $\begin{array}{l}\text { Data } \\
\text { source }\end{array}$ & $\begin{array}{l}\text { Design } \\
\text { Density } \\
\left(\mathrm{Kg} / \mathrm{m}^{3}\right)\end{array}$ & $\begin{array}{l}\text { Design } \\
\text { Thermal } \\
\text { Conductivity } \\
(\mathrm{W} /(\mathrm{m} . \mathrm{K}))\end{array}$ & $\begin{array}{l}\text { GWP } \\
\left(\mathrm{KgCO}_{2} \mathrm{eq}\right)\end{array}$ & EE (MJ) & Reference \\
\hline \multirow[t]{10}{*}{ Glass fibre } & Model & & & 9.42 & 182.6 & \\
\hline & EPD 1 & 15.00 & 0.0425 & 5.27 & 104.93 & $\begin{array}{l}\text { (Knauf Insulation, } \\
2014 b)\end{array}$ \\
\hline & EPD 2 & 17.00 & 0.0395 & 5.90 & 117.30 & $\begin{array}{l}\text { (Knauf Insulation, } \\
2014 c \text { c) }\end{array}$ \\
\hline & EPD 3 & 24.00 & 0.035 & 5.72 & 113.63 & $\begin{array}{l}\text { (Knauf Insulation, } \\
2014 a)\end{array}$ \\
\hline & EPD 4 & 31.00 & 0.033 & 5.27 & 104.84 & $\begin{array}{l}\text { (Knauf Insulation, } \\
2014 d)\end{array}$ \\
\hline & EPD 5 & 10.50 & 0.044 & 5.74 & 119.81 & $\begin{array}{l}\text { (knauf Insulation, } \\
2015)\end{array}$ \\
\hline & EPD 6 & 31.00 & 0.032 & 4.81 & 112.66 & \multirow{4}{*}{$\begin{array}{l}\text { (Resalati et al., } \\
2020)\end{array}$} \\
\hline & EPD 7 & 19.50 & 0.035 & 4.81 & 110.89 & \\
\hline & EPD 8 & 11.50 & 0.04 & 4.89 & 108.92 & \\
\hline & EPD 9 & 20.00 & 0.035 & 7.04 & 128.66 & \\
\hline \multirow{7}{*}{$\begin{array}{l}\text { Expanded } \\
\text { Polystyrene }\end{array}$} & Model & & & 4.11 & 131.11 & \\
\hline & EPD 10 & 15.2 & 0.037 & 6.46 & 342.11 & \multirow{3}{*}{$\begin{array}{l}\text { (Resalati et al., } \\
2020)\end{array}$} \\
\hline & EPD 11 & 15.5 & 0.035 & 4.43 & 127.08 & \\
\hline & EPD 12 & 15.5 & 0.035 & 4.43 & 126.92 & \\
\hline & EPD 13 & 22.5 & 0.035 & 5.20 & 150.91 & \\
\hline & EPD 14 & 16.6 & 0.035 & 4.28 & 123.50 & \\
\hline & EPD 15 & 22.9 & 0.035 & 4.01 & 119.52 & \\
\hline
\end{tabular}

Figure 6 displays the box and whisker plots of the GWP and EE data demonstrating both the modelled values and the EPDs for the glass fibre and expanded polystyrene VIP core material. The box signifies the interquartile range between the 25th and 75 th percentiles with the median and standard deviation represented by the middle line and whiskers respectively. Upon analysing the data for GWP, it can be observed that the median value for glass fibre $\left(5.50 \mathrm{KgCO}_{2}\right.$ eq) is higher than that seen in expanded polystyrene $\left(4.15 \mathrm{KgCO}_{2}\right.$ eq). These results are in line with those obtained from the LCA models (see Table 8). Analysing glass fibre and expanded polystyrene's GWP and EE values in Figure 6 points to outlier values for glass fibre ( $9.42 \mathrm{KgCO}_{2}$ eq for GWP; $182.60 \mathrm{MJ}$ for $\mathrm{EE}$ ) and expanded polystyrene 
(6.46 $\mathrm{KgCO}_{2}$ eq for GWP; $343.11 \mathrm{MJ}$ for EE) associated with the LCA model and EPD 10 (see Table 8). The higher than average values seen for GWP and EE in the LCA model are due to the use of primary virgin glass instead of the $50 \%$ and $80 \%$ recovered waste glass used in EPD 1-9 (see Table 8). Apart from these values, the probability distribution of glass fibre and expanded polystyrene are close for both GWP and EE. The median value for glass fibre (113.15 MJ) was lower than that seen for expanded polystyrene $(127 \mathrm{MJ})$, suggesting that it could have the lowest EE when recycled raw materials are used. The results for GWP and EE highlight that using recycled glass can enable the glass fibre to be environmentally competitive against a lower density material such as expanded polystyrene at a higher vacuum pressure.

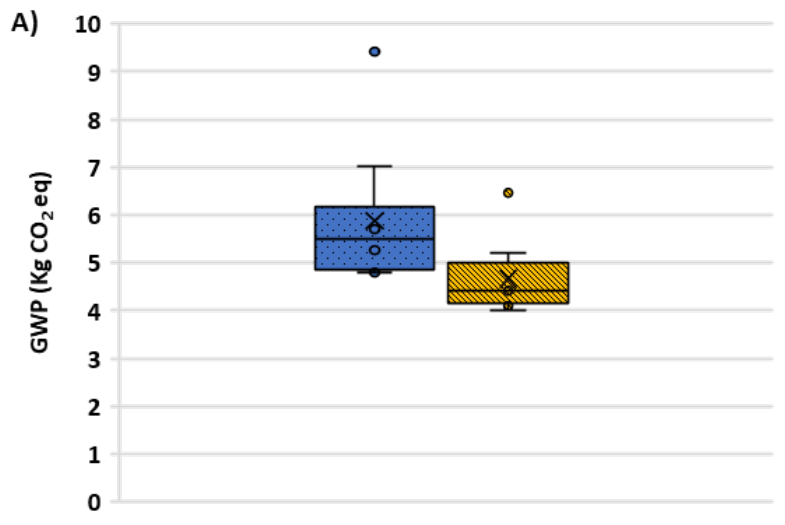

Glass Fibre

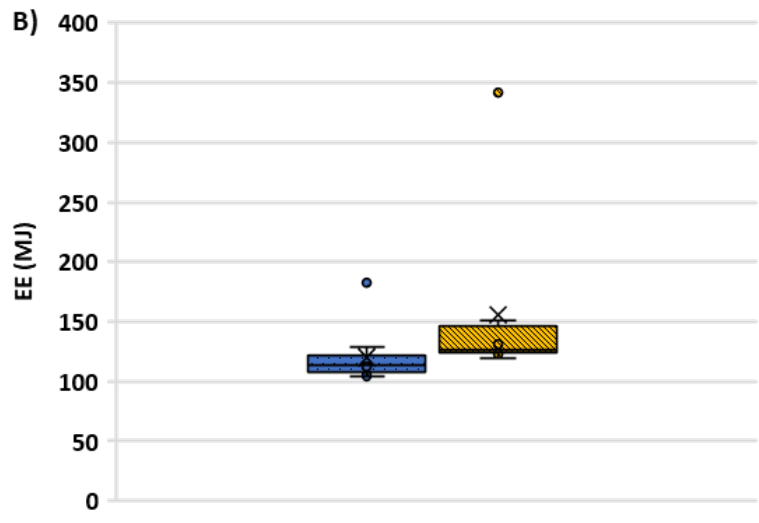

Expanded Polystyrene

Figure 6: GWP and EE of glass fibre and expanded polystyrene when applied in VIP with a U-value of $0.27 \mathrm{~W} / \mathrm{m}^{2} \mathrm{~K}$

Further comparative analysis between the LCA models and the EPDs was done related to the ODP, AP, $E P, P O C P$ and $A D P$ impact categories for glass fibre and expanded polystyrene. Figure 7 shows the box plot of the impact categories with a large probability distribution in the AP and ADP impact categories respectively. Looking specifically at expanded polystyrene, it can be seen that there are outlier values in the AP and EP impact categories. This is according to the data obtained from EPD 10 (see Table 8) showing that the modelled values for the indicators aligns well with the values from the EPDs. The median values indicate that expanded polystyrene has a lower environmental impact in the ODP (1.40E-7 kg R-11 eq), AD (1.10E-2 kg SO 2 eq) and EP (8.76E-4 kg PO 4 eq) impact categories compared with glass fibre. However, due to expanded polystyrene's large probability range in the ADP impact category, the median value indicates that glass fibre (2.30E-4 kg Sb eq) performs better in this category. Overall, the comparative assessment between the modelled values and the literature indicates that expanded polystyrene has the lowest median impact in the GWP, ODP, AP and EP categories while glass fibre performs better in $\mathrm{EE}, \mathrm{POCP}$ and $\mathrm{ADP}$ for the vacuum pressure kept at $100 \mathrm{~Pa}$.
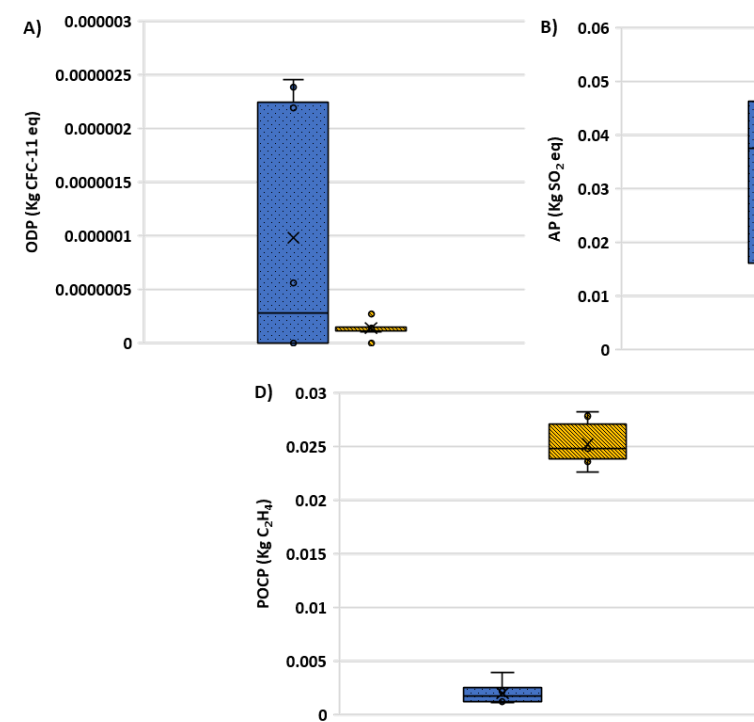
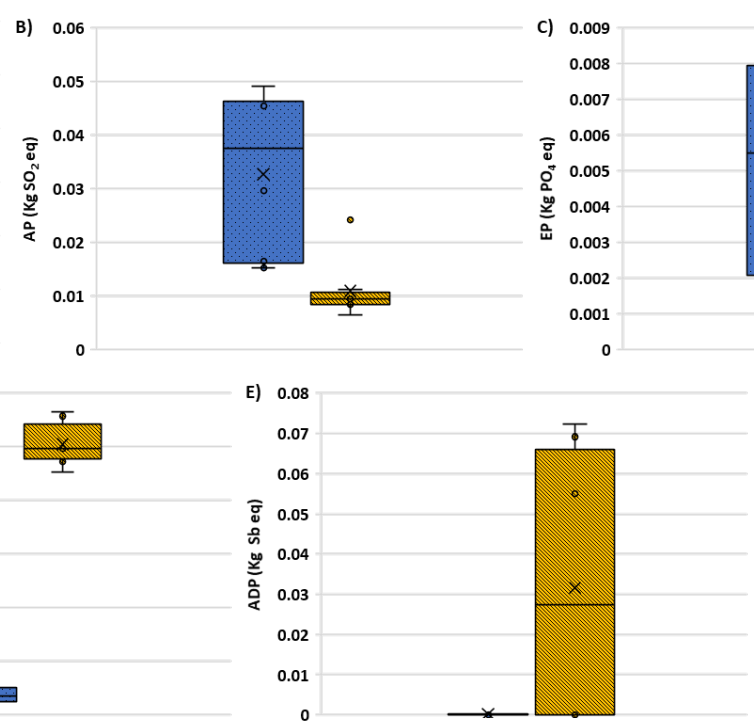

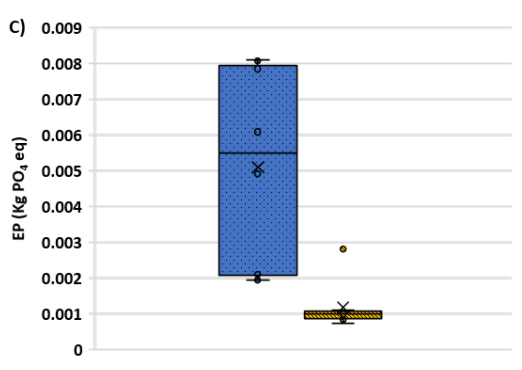

Glass Fibre $\square$ Expanded Polystyrene 
The LCA results for conventional pyrogenic silica VIP production showed that the core material had the highest impact in all of the selected impact categories. This is similar to the results obtained by Karami and their co-researchers when they compared the EPD data of VIPs (Karami et al., 2015). The results were also the same when glass fibre and aerogel were used as the core materials, indicating that the hot spot of VIP manufacture is usually the core material processing.

The comparative environmental assessment of the different core materials showed that the choice of material can significantly reduce the impact of VIP production. According to the results presented in the previous sections, pyrogenic silica, the most commonly used VIP core material, performs poorly compared to the other core materials in terms of the environmental LCA parameters. However, the use of pyrogenic silica has other technical benefits over the use of foam and glass fibre such as a relatively long panel life span and lower sensitivity to vacuum pressure fluctuations due to its structure. This makes it especially ideal for application in buildings with only VIPs using aerogel as the core material rivalling its longevity. The recycling of the core material can help to reduce the environmental impact and it should be adopted by the pyrogenic silica VIP in order to further diminish its environmental impact in addition to that achievable by its longer service life. The environmental impact of manufacturing the pyrogenic silica core material is strongly associated with tetrachlorosilane production and electricity consumption. The use of an eco-friendlier method of producing the inorganic compound alongside the use of renewable electricity sources could potentially make pyrogenic silica more environmentally competitive when compared to glass fibre and low density expanded polystyrene, which both have relatively lower environmental impacts.

This paper does not include the environmental comparison of the core materials during the use phase and this may significantly improve the results obtained for pyrogenic silica due to the avoided impacts of the VIPs prolonged use. Using VIP with pyrogenic silica as the core material can have a lifespan of up to 60 years while that of expanded polystyrene and glass fibre has been shown to have a lifespan of only 15 years due to vacuum loss (Di et al., 2013). End of life scenarios were also not considered and a more detailed cradle to grave analysis taking into account the different recyclability ratio and the recovery potential of each of the different core materials could form the basis for future work. This study provides a cradle to gate comparative environmental assessment to aid relevant stakeholders in making informed decisions related to the VIP selection of the target applications.

The sensitivity of the results to vacuum pressure also needs to be considered when the environmental performance of VIPs is studied. The glass fibre and similar fibrous core material with a higher sensitivity to vacuum pressure fluctuations need to be coupled with envelopes with lower air and moisture permeation rates, thus allowing for a longer service life and lower subsequent conductivity.

\section{Conclusion}

This paper conducted a cradle to gate LCA on conventional pyrogenic silica VIPs. The results show that the pyrogenic silica core had the highest contribution out of all of the selected impact category at $>60 \%$ contribution. A comparative environmental assessment of different VIP core materials was also performed. The LCA of glass fibre, expanded polystyrene, aerogel and a hybrid core made up of a combination of sawdust and pyrogenic silica was compared with that of pyrogenic silica. The use of expanded polystyrene was shown to be more environmentally beneficial than the other core materials in eight (GWP, ODP, AP, EP, ADP, WRD, PENRT and PERT) out of the nine impact categories, when analysed for 100Pa vacuum pressure due to its lower density and without considering its service life. The most commonly used core material, pyrogenic silica, had the highest impact in seven (GWP, AP, EP, ADP, WRD, PENRT and PERT) of the impact categories. The high environmental impact of pyrogenic silica was mainly due to the use of tetrachlorosilane in its manufacture.

The environmental performance of glass fibre and expanded polystyrene were compared with the currently available EPDs and environmental assessment reports. The results indicate that alongside the low density expanded polystyrene, glass fibre performs very well with median values suggesting 
the lowest EE as well as a comparatively low impact in the other environmental impact categories. Recycling the core material and the application of eco-friendly manufacturing techniques should be considered in order to reduce the environmental impact of silica-based VIPs if they are to compete with other alternative core materials environmentally.

\section{Acknowledgement}

The work was partially supported by the Portuguese Foundation for Science and Technology (FCT) through PhD grant PD/BD/135194/2017 under the Eco- Construction and Rehabilitation Programme.

\section{References}

ALAM, M., SINGH, H., BRUNNER, S. \& NAZIRIS, C. 2014. Experimental characterisation and evaluation of the thermo-physical properties of expanded perlite-Fumed silica composite for effective vacuum insulation panel (VIP) core. Energy and Buildings, 69, 442-450.

ALAM, M., SINGH, H. \& LIMBACHIYA, M. C. 2011. Vacuum Insulation Panels (VIPs) for building construction industry - A review of the contemporary developments and future directions. Applied Energy, 88, 3592-3602.

ALAM, M., SINGH, H., SURESH, S. \& REDPATH, D. A. G. 2017. Energy and economic analysis of Vacuum Insulation Panels (VIPs) used in non-domestic buildings. Applied Energy, 188, 1-8.

ALAM M., H. Singh (2019). Sawdust based core material for eco-friendly Vacuum Insulation Panels (VIPs). In proceedings of; 14th International Vacuum Insulation Symposium (IVIS), ed. Atsushi Iwamae, Daisuke Ogura, Masaru Abuku. Pages 7-10.

ALOTAIBI S.S. and Riffat, S., 2014. Vacuum insulated panels for sustainable buildings: a review of research and applications. International journal of energy research, 38(1), pp.1-19.

Azzouz, A., Borchers, M., Moreira, J. and Mavrogianni, A., 2017. Life cycle assessment of energy conservation measures during early stage office building design: A case study in London, UK. Energy and Buildings, 139, pp.547-568.

ASPEN AEROGELS INC. 2015. Environmental Product Declaration Spaceloft Aerogel Insulation. Available: http://greenbuildingencyclopaedia.uk/wpcontent/uploads/2015/12/SpaceloftEPD.pdf [Accessed 16/08/2020].

BAETENS, R., JELLE, B. P., THUE, J. V., TENPIERIK, M. J., GRYNNING, S., UVSL ØKK, S. \& GUSTAVSEN, A. 2010. Vacuum insulation panels for building applications: A review and beyond. Energy and Buildings, 42, 147-172.

BRUNNER, S., STAHL, T. \& GHAZI WAKILI, K. 2012. An example of deteriorated vacuum insulation panels in a building façade. Energy and Buildings, 54, 278-282.

CAPS, R. \& FRICKE, J. 2000. Thermal Conductivity of Opacified Powder Filler Materials for Vacuum Insulations1. International Journal of Thermophysics, 21, 445-452.

CEN, E. 2012. 15804, Sustainability of construction works: Environmental product declarations, Core rules for the product category of construction products. The British Standards Institution.

CHANG, B., ZHONG, L. \& AKINC, M. 2016. Low cost composites for vacuum insulation core material. Vacuum, 131, 120-126.

CHEN, Z., CHEN, Z., YANG, Z., HU, J., YANG, Y., CHANG, L., LEE, L. J. \& XU, T. 2015. Preparation and characterization of vacuum insulation panels with super-stratified glass fiber core material. Energy, 93, 945-954.

CHUNG, S.-Y., SIKORA, P., STEPHAN, D. \& ABD ELRAHMAN, M. 2020. The Effect of Lightweight Concrete Cores on the Thermal Performance of Vacuum Insulation Panels. Materials, 13, 2632.

DE WOLF, C., POMPONI, F. \& MONCASTER, A. 2017. Measuring embodied carbon dioxide equivalent of buildings: A review and critique of current industry practice. Energy and Buildings, 140, 6880.

DI, X., GAO, Y., BAO, C., HU, Y. \& XIE, Z. G. 2013. Optimization of glass fiber based core materials for vacuum insulation panels with laminated aluminum foils as envelopes. Vacuum, 97, 55-59. 
EUROPEAN COMMISSION 2007. Control Reference Document on Best Available Techniques for the Manufacture of Large Volume Inorganic Chemicals-Pyrogenic Silica.

EUROPEAN COMMITEE 2011. Sustainability of construction works-Assessment of environmental performance of buildings-Calculation method. Brussels, Belgium: European Committee for Standardization.

FANTUCCI, S., LORENZATI, A., CAPOZZOLI, A. \& PERINO, M. 2019. Analysis of the temperature dependence of the thermal conductivity in Vacuum Insulation Panels. Energy and Buildings, 183, 64-74.

FRICKE, J., HEINEMANN, U. \& EBERT, H. P. 2008. Vacuum insulation panels-From research to market. Vacuum, 82, 680-690.

GAIKER. 2014. Nanoinsulate Comparative Environmental Impact Assessment Report Available: http://materials.ectp.org/fileadmin/user upload/documents/E2B/NANOINSULATE/D6.2 rep ort v0.1.pdf [Accessed 16/08/20].

Gonçalves, M., Simões, N., Serra, C. and Flores-Colen, I., 2020. A review of the challenges posed by the use of vacuum panels in external insulation finishing systems. Applied Energy, 257, p.114028. IBU.

2014. Environmental Product Declaration Vacuum Insulation Panel. Available:

http://www.vacuum-panels.co.uk/wp-content/uploads/2016/08/EPD-

Porextherm englisch30.03.2015.pdf [Accessed 18/08/2020].

Jusselme, T., Rey, E. and Andersen, M., 2018. An integrative approach for embodied energy: Towards an LCA-based data-driven design method. Renewable and Sustainable Energy Reviews, 88, pp.123-132.

KALN/ES, S. E. \& JELLE, B. P. 2014. Vacuum insulation panel products: A state-of-the-art review and future research pathways. Applied Energy, 116, 355-375.

KARAMI, P., AL-AYISH, N. \& GUDMUNDSSON, K. 2015. A comparative study of the environmental impact of Swedish residential buildings with vacuum insulation panels. Energy and Buildings, 109, 183-194.

KIM, J., LEE, J.-H. \& SONG, T.-H. 2012. Vacuum insulation properties of phenolic foam. International Journal of Heat and Mass Transfer, 55, 5343-5349.

KNAUF INSULATION. 2014a. Environmental Product Declaration Supafil (0.034- $0.036 \mathrm{~W} /(\mathrm{m} . \mathrm{K}))$ blown glass mineral wool insulation Available:

https://www.greenbooklive.com/filelibrary/EN 15804/EPD/Knauf-EN-EPD-0052.1.pdf [Accessed 18/08/20].

KNAUF INSULATION. 2014b. Environmental Product Declaration Supafil (0.040 - $0.045 \mathrm{~W} /(\mathrm{m} . \mathrm{K}))$ blown glass mineral wool insulation. Available:

https://www.greenbooklive.com/filelibrary/EN 15804/EPD/Knauf-EN-EPD-0050.1.pdf [Accessed 18/08/2020].

KNAUF INSULATION. 2014c. Environmental Product Declaration Supafil and Jet Stream (0.037 - 0.042 $\mathrm{W} /(\mathrm{m} . \mathrm{K}))$ blown glass mineral wool insulation. Available: https://www.greenbooklive.com/filelibrary/EN 15804/EPD/Knauf-EN-EPD-0051.1.pdf [Accessed 18/08/20].

KNAUF INSULATION. 2014d. Environmental Product Declaration Supafil Frame $(0.0373 \mathrm{~W} /(\mathrm{m} . \mathrm{K}))$ blown glass mineral wool insulation Available:

https://www.greenbooklive.com/filelibrary/EN 15804/EPD/Knauf-EN-EPD-0053.1.pdf [Accessed 18/08/20].

KNAUF INSULATION. 2015. Environmental Product Declaration glass mineral wool insulation with ECOSE technology $(040 \quad-\quad 046 \quad \mathrm{~W} /(\mathrm{m} . \mathrm{K})) . \quad$ Available: https://www.greenbooklive.com/filelibrary/EN 15804/EPD/EN-EPD-0059.pdf [Accessed 18/08/2020].

LI, C.-D., SAEED, M.-U., PAN, N., CHEN, Z.-F. \& XU, T.-Z. 2016a. Fabrication and characterization of lowcost and green vacuum insulation panels with fumed silica/rice husk ash hybrid core material. Materials \& Design, 107, 440-449.

LI, C., LI, B., PAN, N., CHEN, Z., SAEED, M. U., XU, T. \& YANG, Y. 2016b. Thermo-physical properties of polyester fiber reinforced fumed silica/hollow glass microsphere composite core and resulted vacuum insulation panel. Energy and Buildings, 125, 298-309.

LIANG, Y., WU, H., HUANG, G., YANG, J. \& WANG, H. 2017. Thermal performance and service life of vacuum insulation panels with aerogel composite cores. Energy and Buildings, 154, 606-617. 
LOTTEAU, M., LOUBET, P., POUSSE, M., DUFRASNES, E. \& SONNEMANN, G. 2015. Critical review of life cycle assessment (LCA) for the built environment at the neighborhood scale. Building and Environment, 93, 165-178.

MONCASTER, A. M. \& SONG, J. Y. 2012. A comparative review of existing data and methodologies for calculating embodied energy and carbon of buildings. International Journal of Sustainable Building Technology and Urban Development, 3, 26-36.

NEMANIČ, V. \& ŽUMER, M. 2015. New organic fiber-based core material for vacuum thermal insulation. Energy and Buildings, 90, 137-141.

PARGANA, N., PINHEIRO, M. D., SILVESTRE, J. D. \& DE BRITO, J. 2014. Comparative environmental life cycle assessment of thermal insulation materials of buildings. Energy and Buildings, 82, 466481.

Research and Markets, Vacuum Insulation Panels - Global Market Trajectory \& Analytics, (2020). https://www.researchandmarkets.com/reports/4806375/vacuum-insulationpanelsglobalmarket (accessed Sept 17, 2020).

RESALATI, S., KENDRICK, C. C. \& HILL, C. 2020. Embodied energy data implications for optimal specification of building envelopes. Building Research \& Information, 48, 429-445.

SCHONHARDT, U., BINZ, A., WOHLER, M. \& DOTT, R. 2003. Ökobilanz eines Vakuum-Isolations-Paneels (VIP). University of Applied Sciences, Institute of Energy, Basel, German.

SINGH, H., GEISLER, M. \& MENZEL, F. 2015. Experimental investigations into thermal transport phenomena in vacuum insulation panels (VIPs) using fumed silica cores. Energy and Buildings, 107, 76-83.

SOUST-VERDAGUER, B., LLATAS, C. \& GARCÍA-MARTínEZ, A. 2016. Simplification in life cycle assessment of single-family houses: A review of recent developments. Building and Environment, 103, 215-227.

TETLOW, D., DE SIMON, L., LIEW, S. Y., HEWAKANDAMBY, B., MACK, D., THIELEMANS, W. \& RIFFAT, S. 2017. Cellulosic-crystals as a fumed-silica substitute in vacuum insulated panel technology used in building construction and retrofit applications. Energy and Buildings, 156, 187-196.

WANG, B., LI, Z., QI, X., CHEN, N., ZENG, Q., DAI, D., FAN, M. \& RAO, J. 2019. Thermal Insulation Properties of Green Vacuum Insulation Panel Using Wood Fiber as Core Material. BioResources, 14, 3339-3351.

WONG, C.-M. \& HUNG, M.-L. 2008. Polystyrene Foams as Core Materials Used in Vacuum Insulation Panel. Journal of Cellular Plastics, 44, 239-259.

YANG, C. G., LI, Y. J., GAO, X. \& XU, L. 2012. A Review of Vacuum Degradation Research and the Experimental Outgassing Research of the Core Material- Pu foam on Vacuum Insulation Panels. Physics Procedia, 32, 239-244.

ZACH, J., PETERKOVÁ, J., DUFEK, Z. \& SEKAVČNIK, T. 2019. Development of vacuum insulating panels (VIP) with non-traditional core materials. Energy and Buildings, 199, 12-19.

ZHUANG, J., GHAFFAR, S. H., FAN, M. \& CORKER, J. 2017. Restructure of expanded cork with fumed silica as novel core materials for vacuum insulation panels. Composites Part B: Engineering, 127, 215-221. 